\title{
CRITICAL REVIEW OF STILLING BASIN MODELS FOR PIPE OUTLET WORKS
}

\author{
Bharat Kumar Gehlot ${ }^{1}$, H.L.Tiwari ${ }^{2}$ \\ ${ }^{I}$ PG Research Scholar, Civil Engg. Dept, MANIT Bhopal (M.P.), India \\ ${ }^{2}$ Faculty, Civil Engg, Dept, MANIT Bhopal (M.P.), India
}

\begin{abstract}
When water released from an outlet in reservoir whether from gate, valves or tunnels or conduits and over spillway, it attains high velocity. This high velocity is generated by virtue of changing its potential head from the reservoir level to the level of the river on the downstream. This higher velocity causes scouring downstream structure. To safe guard against such scouring, suitable stilling basin are designed, in which energy of flowing water is reduced. In this paper, different types of stilling basin models designed by past investigators are presented with their appurtenances and these models are compared on the basis of stilling basin length.
\end{abstract}

Keywords: Gate, Tunnels, Spillway, Stilling Basin, outlet

\section{INTRODUCTION}

Water flowing through a pipe outlet or over a spillway has a very high kinetic energy because of the conversion of entire potential energy into kinetic energy. If the water flowing with such a high velocity discharged directly into the downstream channel by pipe outlet or spillway, serious scour of downstream stream may occur. If scour is not properly controlled, it may extend backward to the hydraulic structure and may be endanger to the dam and spillway. Energy dissipator or stilling basin is a structure design to the reducing the velocity of flow to the acceptable limit and protect downstream areas from erosion. In a stilling basin, kinetic energy is converted into turbulence energy and ultimately into heat. Stilling basins are generally provided with various appurtenances such as chute blocks, baffle block, end sill and baffle wall, etc. These appurtenances can help in reducing the energy of flowing water by offering resistance of flow and may stabilise the flow in a shorter length of the stilling basin.

Lot of works has been carried out related with the design of stilling basin models with different appurtenances like baffle blocks, intermediate sill, impact wall, end sill, etc. Bradly and Peterka[1], Fiala and Albertson[5], Keim[12], Flammer[6] et. al, Garde et al.[7], Goel and Verma[8], Goel)[11], Tiwari \& Tiwari[22], Tiwari [21] and Tiwari et.al[15,16 \& 20] investigated the hydraulic energy dissipator with plain impacted wall, baffle block, intermediated sill and end sill. This paper describes about the different type of stilling basin models carried out by past investigators.

\section{HYDRAULIC JUMP TYPE STILLING BASIN}

The hydraulic jump basin is generally used for energy dissipation of pipe outlet and prevents scouring in downstream side. The hydraulic jump type stilling basin dissipates about 10 to 85 percent energy, which depend on the Froude number of the incoming flow and available tail water depth (Tiwari et al. 2010). In this type stilling basins, the $\mathrm{L} / \mathrm{D}$ ratio varies from 11 to 91 , where $\mathrm{L}=$ length of the stilling basin and $\mathrm{D}=$ diameter of pipe outlet. An unconstrained (no obstacles in the flow on the basin) hydraulic jump effectively dissipates energy, but the large length required. For an economical perspective, as the entire jump must be constrained within a concrete structure with the help by various appurtenances like chute blocks, baffle blocks and end sill. The purpose of these appurtenances is to increase turbulence and help in stabilization of the jump, which reduces the required length of the stilling basin and provided safety against sweep out caused by inadequate tail water depth. These appurtenances increase the efficiency of the jump and decrease the required length of the stilling basin to dissipate the energy.

\section{USBR TYPE VI (IMPACT WALL) STILLING BASIN}

It is developed by Bradley \& Peterka [1] for circular pipe outlet. It is impact wall energy dissipater, contained in a relatively small boxlike structure. In this case energy dissipation is independent of tail water depth, but a moderate depth of tail water will improving performance. An impact basin provides a positive barrier within the flow area. Energy dissipation is accomplished through the turbulence created by the loss of momentum as flow entering the basin impacts by a baffle wall, and the direction of the flow is changed. Further dissipation is produced as water builds up behind the baffle wall to form a highly turbulent backwater zone. Then flow is passed through the baffle wall to the open basin and out to the receiving channel. A sill at the basin end reduces exit velocities by breaking up the flow across the basin floor. 


\section{HUMP TYPE STILLING BASIN}

It has been designed by Elevatorski [3] in this stilling basin placed below the level of downstream Chanel but is not submerged by tail water. The hump is used to spread the jet of water throughout the width of channel and help in formation of force hydraulic jump. The crest level of hump is kept the river bed level of the channel. The shape and size of the hump is a significant contribution of energy dissipation. The height of hump should be sufficient to spread the water jet throughout the width of basin. If the hump height should be kept high then jet would not spread out completely to the full width of downstream channel and height is low, the tail water for small flows discharge will submerge the hydraulic jump.

\section{MANIFOLD STILLING BASIN}

Fiala and Albertson [5] designed Manifold stilling basin for rectangular pipe outlet. This stilling basin worked on the principle of diffusion of submerged jet. This type of energy dissipater is not suitable for circular outlets and under situations having chances of blockage of openings due to floating debris. It required large length of stilling basin.

\section{CONTRA COSTA STILLING BASIN}

Contra costa stilling basin was developed by Keim [12] for the culverts. It is suitable for the depth of flow is less than half of the culvert diameter and velocity of water is high. It is worked on the concept of energy loss by a combination of impact action and hydraulic jump inside the stilling basin. The water jet strike on barriers and and the direction of water flow change in this mechanism consisted of the production of large scale turbulence and eddies during distribution of the jet.

\section{HOOK BASIN}

The hook basin developed by the University of California in cooperation with the California Division of Highways and the Bureau of Public Roads [4]. The basin was developed for large arch culverts with low tail water or no tail water, but it's is used for both circular and rectangular conduits. In this type energy dissipater hook type baffle blocks is used. The energy in a hook basin is dissipated by the hooks reversing and turning the momentum of flow upon the surrounding flow to rapidly widen the flow and reducing the overall velocity. The floor can be flared slightly outward in the downstream direction. This basin is suitable for a small drainage channel to prevent scour.

\section{UTAH STATE VNIVERSITY STILLING BASIN}

Flammer et. al [6] developed Utah state university stilling basin for a transition portion from pipe outlet section to open channel section. In this type of stilling basin, energy is dissipated by shear friction, pressure drag and diffusion action of submerged water jet. Its designed depends on discharge, pipe outlet diameter and available tail water depth in downstream side. It is applicable merely for fully submerged outlets and $\mathrm{W}_{\mathrm{b}} / \mathrm{D}$ always kept more than 6 . The depth requirement of stilling basin is too much which may not be provided physically in many situations and also affected by debris being entrapped in the basin endangering the safety of structure.

\section{COUNTER CURRENT STILLING BASIN}

Counter current stilling basin developed by Vollmer and Khader [24] for circular pipe outlet. It is work on the principle of the combination of impact action and breaking of water jet. V shaped structure is dividing the water jet in two parts by placed on the floor of the basin known as splitter block. A gap of $0.2 \mathrm{D}$ is provided below the impact wall of circular arc shape to pass low discharges $(\mathrm{D}=$ diameter of the outlet). The length and the width of stilling basin are kept 7.3D and 4D respectively. In this stilling basin, appurtenances such as a diffuser of triangular wedge shape, an impact wall of circular shape having bottom gap equal to $0.2 \mathrm{D}$ and one rectangular end sill are recommended. The drain holes to be provide the end sill would help in removing the sediments at low discharges.

\section{GARDE'S STILLING BASIN MODELS}

The energy dissipator designed by Garde et al.[7] for circular pipe outlet. This stilling basin is work on the principle that the water jet is spread throught the width of stilling basin by curved splitter which placed 1D distance from pipe outlet where $\mathrm{D}$ is the diameter of the pipe. The grid blocks and intermediate sill also used to improve the performance of stilling basin. It is suitable for Froude number ranging from 1.7 to 7.0. All the dimensions of the stilling basins are in terms of diameter of the pipe outlet. The stilling basin length is $12 \mathrm{D}$ which is large to make uneconomical and construction of splitter block and grid of blocks is not easy.

Pillai and Goel [13] used the wedge shaped splitter blocks having a vertex angle of $150^{\circ}$ in the stilling basin for pipe outlets. This splitter block found to be very effective in spreading the jet of water over the width of the stilling basin within a shorter length and has better energy dissipation. They had also found that the performance of the stilling basin improves by using rounded end sill instead of rectangular or sloping one.

Goel and Verma [8] was development of an energy dissipator for circular pipe outlets on Froude number ranging 1.70 to 5.50 . It was used wedge shaped splitter block with vertex angle $150^{\circ}$ and the sloping end sill inside the stiling basin. Wedge shaped block with vertex angle $150^{\circ}$ splitter block very effective in spreading the water. The sloping end sill enhances the performance of stilling basin by high velocity filaments were lifted up from the bottom flow which resulted into lesser scour in downstream side of stilling basin.

Goel and Verma [9] further reduced the length of the stilling basin as suggested by Garde to 8 times and 6 times 
of the pipe diameter by replacing the grid type of baffle wall with solid one and a curved splitter with wedge shaped splitter block. The performance of the stilling basin improved significantly.

Goel and Verma [11] carried out study of stilling basins for pipe outlets for the Froude Number range of 1.7-5.5. By using different appurtenances such as splitter block, impact wall, baffle blocks and end sill there is a reduction in stilling basin length up to the extent of $25 \%$ of the original and at the same time there is improvement in the performance of the basin. In this study the basin floor is kept at the invert level of the pipe.

Goel and verma [10] studied the Garde stilling basin. He developed new stilling basin model for circular pipe outlet which has better performance than Garde stilling basin in a length of $6 \mathrm{~d}$ as compare to $12 \mathrm{~d}$ of Garde stilling basin. Study carried out by Goel is for circular pipe outlet.

Tiwari et al. [16] developed new stilling basin for non circular pipe outlet for the Froude number range 1.85 to 3.85. They developed new stilling basin by changing the shape of the end sill and other configuration of stilling basin is same as USBR VI stilling basin. Its gives a stilling basin with plain impacted wall stilling basin whose location from pipe outlet is fixed $3 d$ (d=equivalent dia. of pipe) distance from pipe outlet. This study also revealed that the sloping vertical end sill (slope $1 \mathrm{~V}: 1 \mathrm{H}$ ) dissipates more energy of flow and found to perform better for all flow conditions as compared to other end sills tested for rectangular pipe outlet basin. It is concluded that the end sill of basin has a great contribution in energy dissipation and also, it improved the flow pattern and reduces the basin length.

Tiwari \& Tiwari [19] developed the new stilling basin for non circular pipe outlet on Froude numbers range 1.85 to 3.85. The intermediate rectangular sill of height $1 \mathrm{~d}$ (d=equivalent dia. of pipe) is placed $4 \mathrm{~d}$ distance from pipe outlet in a stilling basin. The intermediate sill is affects the performance of stilling basin due to change in the flow pattern in the basin. This stilling basin is more efficient as compared to USBR VI stilling basin.

Tiwari [17] designed the new stilling basin for rectangular pipe outlet with the varying of the location and size of impact wall which affect the performance of stilling basin due to change in the flow patterns. It gives a new impact wall stilling basin model. The length of basin reduced to seven times the diameter of pipe outlet. This stilling basin dissipates more energy with the help by increasing the surface area by which skin friction increase. In this model, the basin length reduced to $29 \%$ with better performance as compared to USBR VI stilling basin model .

Tiwari et.al [20] developed the stilling basin model by using square intermediate sill and it was reported that the performance of developed model improve as compares USBR VI stilling basin model.

\section{COMPARISON OF DIFFEREN T TYPE OF STILLING BASIN MODELA}

After gone through literature review, different basin has been compared in term of length as given in Table-1. Table1 clearly indicates that hydraulic jump type stilling basin required longest length for dissipation of hydraulic energy. The Contra costa stilling basin is used merely for culverts when the depth of flow is equal or less than half the dia. of culvert. Type USBR VI stilling basin is mostly used for pipe outlet. Garde stilling basin model is efficient as compare to stilling basin type USBR VI but more basin length required. Goel and Verma reduce the basin length with the help of splitter blocks for circular pipe work. In Tiwari stilling basin model the length of basin is reducing from $8.4 \mathrm{~d}$ to $7 \mathrm{~d}$ for rectangular pipe outlet by using proper design of impact wall along with end sill.

\section{CONCLUSIONS}

This paper summarises several type of stilling basin for circular and rectangular shape pipe outlet. The hydraulic energy dissipator with plain impacted wall, baffle block, intermediated sill and end sill are analyzed by past researchers. But after brief literature review, it was found that there is no direct design of energy dissipater for the trapezoidal cut impact wall. As the jet of water comes out from pipe outlet, it strikes the impact wall but only the central portion of the impact wall is useful in the dissipation of hydraulic energy and side portion of the impact wall is of no use. Hence, to economise the material of the plain impact wall it may be replace by trapezoidal cut impact wall. Hence there is a need to design the stilling basin models with trapezoidal cut impact wall.

Table-1: comparison of length of different stilling basins for pipe outlet

\begin{tabular}{|l|l|l|l|l|}
\hline S. No & Name of Stilling Basin & Length & Appurtenances & Remarks \\
\hline 1. & Hydraulic Jump Type & $11 \mathrm{~d}-91 \mathrm{~d}$ & --- & Longest \\
\hline 2. & $\begin{array}{l}\text { USBR TYPE VI Stilling } \\
\text { basin Energy }\end{array}$ & $8.4 \mathrm{~d}$ & Impact wall and End sill & Generally used in pipe outlet \\
\hline 3. & Manifold Stilling Basin & --- & --- & Complicated \\
\hline 4. & Garde's Stilling Basin & $12 \mathrm{~d}$ & $\begin{array}{l}\text { Spillter block, impact wall and } \\
\text { End sill }\end{array}$ & Developed in India \\
\hline 5. & $\begin{array}{l}\text { Counter Current Type Energy } \\
\text { Dissipator }\end{array}$ & $7.3 \mathrm{~d}$ & Spillter block and Impact wall & Construction cost high \\
\hline 6. & Contra Costa Energy & $6 \mathrm{~d}-22 \mathrm{~d}$ & Intermediate sill & Depends on dia., Fr and for \\
\hline
\end{tabular}




\begin{tabular}{|l|l|l|l|l|}
\hline & Dissipator & & & culverts only. \\
\hline 7 & Hook Basin & --- & Friction blocks & Suitable for small drain channel \\
\hline 8. & Goel and Verma & $6 \mathrm{~d}$ to $8 \mathrm{~d}$ & $\begin{array}{l}\text { Impact wall, Spillter block and } \\
\text { End sill }\end{array}$ & For circular pipe outlet \\
\hline 9. & Goel Stilling Basin & $6 \mathrm{~d}$ to 12 d & $\begin{array}{l}\text { Impact wall, Splitter block, } \\
\text { Friction blocks and End sill }\end{array}$ & For circular pipe outlet \\
\hline 10. & Tiwari Stilling Basin & $8.4 \mathrm{~d} 7 \mathrm{~d}$ & Impact wall and End sill & $\begin{array}{l}\text { More efficient as compare to } \\
\text { USBR type VI stilling basin for } \\
\text { nom circular pipe outlet }\end{array}$ \\
\hline
\end{tabular}

\section{REFERENCES}

[1]. Bradley J.N. \& Peterka A.J. (1957). "Hydraulic Design of Stilling Basins". Journaln of Hydraulic Division ASCE., 1401-1406.pp-(1-6 papers).

[2]. Charles, E. Rice and Keim.C. Kadavy, (1991). "HGL Elevation at Pipe Exit of USBR Type VI Impact Basin”. Journal of ASCE., Hydraulic Engg. Div., Vol.117, Paper No.26005, No- 7.

[3]. Elevatorski, Edward, A. (1959). "Hydraulic Energy Dissipators". McGraw Hill Book Company, Inc., New York.

[4]. FEMA(2010), Technical Manual : Outlet Works Energy Dissipators,P-679

[5]. Fiala, J. R. and Maurice, L. Albertson. (1961). "Manifold Stilling Basins". Journal ASCE, Hydraulic Div. No 4, Vol. 87, Paper no 2863, pp.55-81,

[6]. Flammer, G.H, G.V.Skogerboe, C.Y. Wei and H. Rasheed (1970). "Closed Conduit to Open Channel Stilling Basins". Journal of A.S.C.E., Irrigation and Drainage Div, Vol.96, Paper no 7124, pp.1-10..

[7]. Garde, R .J. Saraf,P.D. and Dahigaonkar, D.J. (1986). "Evolution of Design of Energy Dissipator for Pipe Outlets". J. of Irrigation \& Power, pp.145-154,

[8]. Goel Arun and Verma, D.V.S. (1999). "Improved Design of Energy Dissipators for Pipe Outlets". J. of Irrigation and Drainage Systems, Kluwer Academic Pub., The Netherlands, Vol.13, No.4, pp. 313-320,

[9]. Goel, A.\&Verma, D.V.S. (2000). "Development of Economical Energy Dissipators for Pipe Outlets with Low Inflow Froude Numbers". Asian Institute of Technology, A.P.D.,I.A.H.R., Thailand.

[10]. Goel Arun and Verma, D.V.S. (2006). "Alternate Design of Energy Dissipators for Pipe Outlets". J. of Irrigation and

Drainage Systems, The Netherlands, Vol.13, No.4, pp. 313320 ,

[11]. Goel Arun (2007). "Experimental Study on Stilling Basins for Square Outlets". $3^{\text {rd }}$ WSEAS International Conference on Applied and Theoretical Mechanics, Spain, December 14-16, 2007, pp. 157-162

[12]. Keim, S.R. (1962). "Contra Costa Energy Dissipator". Journal of A.S.C.E., Hydraulic Division, Paper 3077, pp. 109-122,.

[13]. Pillai, N. N. and Goel, Arun (1989). "Hydraulic Jump Type Stilling Basins for Low Inflow Froude Numbers". Journal of Hydraulic Division, ASCE: 115, pp 989-994.

[14]. Tiwari, H.L., Goel, A. and Gahlot, V.K. (2010). "Stilling Basins Below Outlet Works -An Overview".
International Journal of Engineering Science and Technology Vol. 2(11), 6380-6385

[15]. Tiwari, H.L., Goel, A. and Gahlot, V.K. (2011). "Experimental Study of Effect of End Sill on Stilling Basin Performance". International Journal of Engg. Sci. and Technology, 3(4), 3134-3140.

[16]. Tiwari, H.L, Gahlot, V.K. and Tiwari Seema (2013). "Reduction of Scour Depth Downstream of Stilling Basin". International Research Journal of Engineering Sciences: vol.2(7). pp.20- 25.

[17]. Tiwari, H.L. (2013). "Design of Stilling Basin with Impact Wall and End Sill". International Research Journal of Resent Sciences :vol. 2(3). pp.59-63.

[18]. Tiwari, H.L. (2013). "Analysis of Baffle Wall Gap in the Design of Stilling Basin Models", International Journal of Civil Engineering and Technology :vol. 4(4). pp. 66-71. [19]. Tiwari, H.L. and Tiwari Seema (2013), "Design of Stilling Basin Models with Intermediate sill', Journal of Science, Technology and Management, 2( 4), pp.66-71.

[20]. Tiwari, H.L. Pawar A., Gehlot, B .K.. and Singh, J. (2014), "Study of Shape of Intermediate Sill on The Design of Stilling Basin Model', International Jounral of Research in Engg and Techonolgy (IJRET), Vol. 3, No. 4, Pp.133-138 [21]. Verma, D.V.S. and Goel, Arun. (2000). " Stilling Basins for Pipe Outlets using Wedge- Shaped Splitter Block". Journal of Irrigation and Drainage Division, ASCE, Vol. 126, No.3, pp.179-184.

[22]. Verma, D.V.S. and Goel Arun (2001). "Model Studies on Stilling Basins for Pipe Outlets". J. of Irrigation and Drainage Systems, Kluwer Academic Publisher, The Netherlands. Vol.15, No.1, pp. 81-91,

[23]. Verma D.V.S. \& Goel, Arun. (2003). "Development of Efficient Stilling Basins for Pipe Outlets". Journal of Irrigation and Drainage Division, ASCE, Vol.115, No.7, pp.194-200.

[24]. Vollmer, E. and Khader M.H.A. (1971). "Counter Current Energy Dissipator for Conduit Outlets". International J. of Water Power, pp. 60-263, 